\title{
The Effect of Short Course to the Students' Ability in Translating English Verbal Sentence
}

\author{
Susi Ekalestari ${ }^{1}$, Abdurrozzaq Hasibuan ${ }^{2}$, P Purwarno $^{1}$ \\ \{susi.ekalestari@sastra.uisu.ac.id,rozzaq@uisu.ac.id, purwarno@sastra.uisu.ac.id\} \\ ${ }^{1}$ English Department, Faculty of Literature, Universitas Islam Sumatera Utara, Medan \\ ${ }^{2}$ Industrial Engineering, Faculty of Engineering, Universitas Islam Sumatera Utara, Medan
}

\begin{abstract}
This research is to see the effect of short course to the students' ability in translating English verbal sentences. The short course is fulfilled in three meetings for each group. However, the short course utilizes new module and modified approaches in the application. The data analysis is obtained by giving a test to the samples. The samples are divided in two groups; students in social class and students in physical class of which the students are not more than 30 persons for each class. The data analysis is completed by using Wilcoxon Signed Ranks Test due to the non-parametric data. The result shows that the alpha value of the groups through the Asymp. Siq (2-tailed) are less than 0.05 alpha. The alpha value of group A is .001 , and the alpha value of group B is .000 . They mean that there is significant effect of the short course to the students' ability in translating English verbal sentences which is proved by the increase of the students' score in the post-test or after the short course.
\end{abstract}

Keywords: Course, Students, Ability, Translating, Verbal Sentence

\section{Introduction}

English is an international language that should be learned by all people in the world especially those who are involved in academic activity or business. It is so necessary because English is used in as a tool of communication among people from different countries. As it is said by Horiguchi (Horiguchi. 2015) that English is a global language which triggers many countries to list English as one of compulsory subject in educational field. It is to adjure the generation with good competitive competence on language. However, English teachers still have formidable task to develop new paradigm either in modular teaching or approaches in teaching related to errors in grammar (Nava. 2017).

In fact, most students, especially, those of Indonesia found Engish as a very difficult language to learn and to understand. It is hard to have good competence in Engish communication. This is proved by the score of the students at school. The worse phenomenon is that the students have aready known that they will get bad score on their exam. And because of that, they are triggered to do cheating. The cheating itself is mostly done and colaborated with their teachers. They try to get information about the contain of the test and ask the answer from their teacher to get high score. Responding to the reality of the importance of English nowadays, the researchers try to investigate certain short course on English focusing on English verbal sentence to the students of Senior High School in Medan, Indonesia. English verbal sentence is a topic in which many errors are found related to the grammar rules. 
Although, the grammar rules have been taught repeatedy in the different level of education, error are often found in the answer sheets of the students. Furthermore, the short course is also to see its effect on the students' ability in translating English verbal sentence by minimizing making errors. Translation in the test used in this research because one start from translating to communicate in other language. As said by Pedro (Pedro \& Carmen. 2015) that it is plausible hypothesis that students are primed by verbatim corpus of second or foreign language in literal translation. And it is proved by them that students should be offered by more corpus data like dictionaries. It is to make the students larn the terms approppriately and know how to use the terms. Literal Translation is the translation modality with most occurrences (43\%). This may indicate a tendency to the proximity of the syntax of both texts, although it did not make the translated text less natural in the target language (Clara et.al. 2017. p. 97). It emphasizes that modality verbs need to be considered in translating. The students should really now how to use and how to translate modality verbs in their translation. Other research found that "Resulted from existence of special forms of "temporal correlation" of an action in English two ways of designating action in the past: simple form of past and form of perfect of the present. It resulted in need of their differentiation to some additional sign (Tulegen. 2016. p. 207)." It implies that translating from native language (Bahasa Indonesia) into target language (English), the students should have good basic knowledge on tense. It is related to verb forms and ,of course, auxiliary verbs which play important role in tranlsating. It is supported by Kalmazova (Kalmazova. 2016) who found in his research that modal verb shall was found problematic in translating a contract by Law Students. He emphasized that the students found some difficuties in translating legal correspondence such as universal lexical, grammatical, syntactic, and cultural equality. Again, grammatical difficulties are found by students. It is really a task for researchers to find any solution for these matters.

The researchers are triggered by this apprehensive condition of the students in learning English to find a new breakthrough in teaching English. The short course program is also made referred to HESD (Higher Education Sustainability Development) program. Seatter, C.S \& Ceulemans, K (Seatter, C.S \& Ceulemans, K . 2017) inferred that HESD program has capacity in formal education to promote transpormative learning. This program allows the students to be active, creative, critical, and transformative in learning. In this research, the researchers tries to treat the Indonesian students related to translating English verbal sentences by giving short course to them. Therefore, the theory tht is dopted in this research is constructivist theory. Constructivist theory is a mening-making theory (Richardson,V, 1997). The theory suggests that the students should be creative to get a new knowledge with their own understanding by using their prior knowledge and the new information of the new knowledge. The reseachers would like to see the effect of the short course to the students' ability in translating English verbal sentences. Therefore, the research questions in this research are:

1. How does the short course effect the students' ability in translating English verbal sentence?

2. Is the short course able to reduce the students's error in translating English verbal sentence?

Based on the research questions above, the researchers might draw their research hypothesis as follows:

1. $\mathrm{H}_{0} 1$ :There is no significant effect of the short course to the students' ability in translating English verbal sentence.

2. $\mathrm{H}_{0} 2$ : There is no signficant difference of the students' score before and after the short course in translating English verbal sentence. 


\section{Methodology}

\subsection{Research Design}

The research design adopted in this study is quantitative research in which the data are analyzed statistically by using SPSS 20 . Furthermore, it goes based on the research questions of this research. They are to see the effect of the short course to the students' ability in translating English verbal sentence by considering the improvement of the students' score in the post-test.

\subsection{Sample}

The samples of this research are the students of Senior High School in Medan, Indonesia. It is from Ksatria School. This school has two majors. They are social class and physical class. Both majors are taken to be the samples in this research. However, they are the third year students. There are 14 students in social class and 19 students in physical class.

\subsection{Instrument}

The instrument that is used to collect the data in this research is test. The test is given before and after the short course. Therefore, there is pre-test and post test. The test itself contains verbal sentence in Bahasa Indonesia that should be translated by the students. The questions in the pre-test and post-test are the same questions. Furthermore, the questions are those of basic verbal sentences which contain positive sentence, negative sentence and yes-no question. The pre-test is given to see the problem that might be difficulties for the students. It is seen from the answers of the students. Then the short course is given related to the difficulties found by the students. The researchers call this period is treatment class. The treatment class is fulfilled in one day only. Then, the researchers give the students the posttest. It is to see the score of the students. If the score is higher, it means that the short course works well.

\subsection{Data Collection and Analysis.}

To collect the data, the researchers give test to the respondents of the research. Therefore, the data is in the form of scores. The score is obtained during the short course. The short course is done separately to both groups with the same treatment.

Table 1: Short Course Schedule for Group A (Social Class)

\begin{tabular}{lccc}
\hline No. & Day / Date & Time & Activity \\
\hline $\mathbf{1}$ & Monday/ 6 February 2017 & $11.00-12.00 \mathrm{AM}$ & Motivation and Pre - Test \\
$\mathbf{2}$ & Friday/ 10 February 2017 & $09.15-10.15 \mathrm{AM}$ & Treatment \\
$\mathbf{3}$ & Friday / 10 February 2017 & $11.00-12.00 \mathrm{AM}$ & Post - Test \\
\hline
\end{tabular}

Table 2: Short Course Schedule for Group B (Physical Class)

\begin{tabular}{lccc}
\hline No. & Day / Date & Time & Activity \\
\hline $\mathbf{1}$ & Saturday / 4 February 2017 & $08.15-09.15 \mathrm{AM}$ & Motivation and Pre - Test \\
$\mathbf{2}$ & Saturdy / 4 February 2017 & $09.15-10.15 \mathrm{AM}$ & Treatment \\
$\mathbf{3}$ & Wednesday / 8 February 2017 & $11.00-12.00 \mathrm{AM}$ & Post - Test \\
\hline
\end{tabular}


From the schedule, it is seen that on the first day, the dominant activity in the class is giving motivation. Motivation is considered really important before giving material or lesson. A research found that motivation in learning is a complex construct because motivation does not come solely from the students themselves, but also from parents, teachers, and social interaction. If all the sources of the motivation are fulfilled, then learning target will be easier to be achieved. However, in Indonesia, the students' motivation dominantly is from random sources, so it is the teachers' task to put them into a good package of motivation to meet the teaching achievement (Wong. R.M.H. 2012).

Furthermore, the researcher also give feedback to the students during the short course. Feedback is considered good for students to be better in their learning process. As found by Irawati (2012) who concluded in her research that teacher's feedback is very good for school students because they still need the intervention from the teacher in their learning process. Furthermore, she also concluded that the combination of correction symbol and conference is effective to be applied. Corrective symbol means that the teacher gives a symbol of the mistake made by the students. Then the student will correct the mistake themselves. Conference means the teacher gives explication and explains the mistake made by the students, and the student correct the mistake themselves.

Table 3: The Score of Group A (Social Class)

\begin{tabular}{|c|c|c|}
\hline \multirow[t]{2}{*}{ No. } & \multicolumn{2}{|c|}{ Score } \\
\hline & Pre-Test & Post-Test \\
\hline 1 & 20 & 19 \\
\hline 2 & 12 & 25 \\
\hline 3 & 8 & 13 \\
\hline 4 & 8 & 17 \\
\hline 5 & 7 & 15 \\
\hline 6 & 6 & 15 \\
\hline 7 & 3 & 15 \\
\hline 8 & 3 & 19 \\
\hline 9 & 3 & 14 \\
\hline 10 & 3 & 21 \\
\hline 11 & 2 & 17 \\
\hline 12 & 1 & 16 \\
\hline 13 & 1 & 18 \\
\hline 14 & 0 & 16 \\
\hline
\end{tabular}

Table 4: Score of Group B (Physical Class)

\begin{tabular}{lcc}
\hline No. & \multicolumn{2}{c}{ Score } \\
& Pre-Test & Post-Test \\
\hline 1 & 24 & 37 \\
2 & 16 & 18 \\
3 & 16 & 30 \\
4 & 13 & 25 \\
5 & 12 & 15 \\
6 & 12 & 12 \\
7 & 11 & 30 \\
8 & 10 & 22 \\
9 & 9 & 13 \\
10 & 7 & 18 \\
11 & 7 & 11 \\
12 & 7 & 27 \\
\hline
\end{tabular}




\begin{tabular}{ccc}
\hline No. & \multicolumn{2}{c}{ Score } \\
& Pre-Test & Post-Test \\
\hline 13 & 7 & 13 \\
14 & 5 & 15 \\
15 & 4 & 20 \\
16 & 3 & 25 \\
17 & 3 & 20 \\
18 & 3 & 22 \\
\hline
\end{tabular}

\subsection{Data Normality Test}

Data normality test is utilized to see the distribution of the data. In other words, it is to know that the data are normally distributed. To see the chart of the normal distribution of the data, the researcher adopts the method of Normal Probability Plots in testing the data for both groups. The followings are the charts that show the normal distribution of the data of the two groups in this research. The data distribution are normal because the data spread around the diagonal line of the chart.

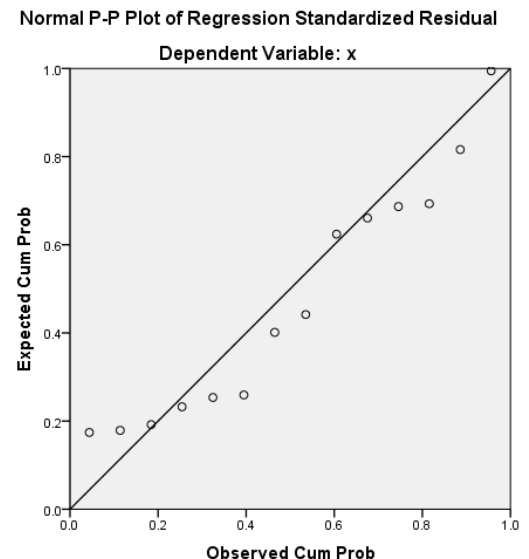

Fig. 1. Chart of data distribution (Normal Probability Plots) of Group A (Social Class)

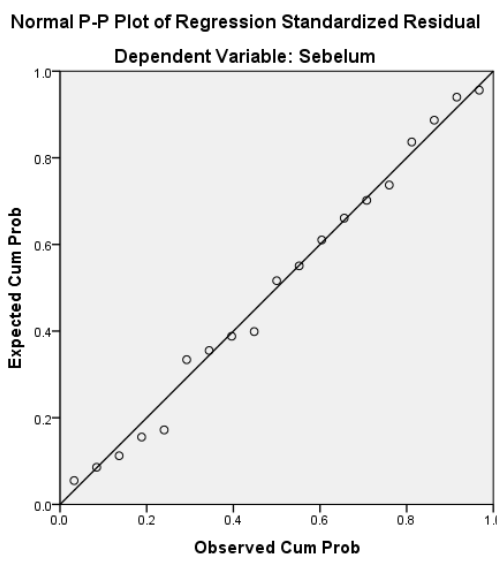

Fig. 2. Chart of data distribution (Normal Probability Plots) of Group B (Physical Class) 
To see the normal distribution of the data from the Constanta value or Asymp.sig value, the researcher adopts the method of Kolmogorov-Smirnov Z. Both data show that the Asymp.sig value are larger than 0.05 , then the data are distributed normally. The Asymp.sig value of group A (Social Class) is .343 and .861). And the Asymp.sig value of group B (Physical class) is .757 and .989

Table 5. Group A (Social Class)

\begin{tabular}{llrr}
\hline \multicolumn{4}{c}{ One-Sample Kolmogorov-Smirnov Test } \\
$\mathrm{N}$ & & $\mathrm{x}$ & $\mathrm{x} 1$ \\
Normal & Mean & 5.50 & 17.14 \\
Parameters $^{\mathrm{a}, \mathrm{b}}$ & Std. & 5.374 & 3.134 \\
& Deviation & & \\
Most Extreme & Absolute & .251 & .161 \\
Differences & Positive & .251 & .161 \\
& Negative & -.153 & -.104 \\
Kolmogorov-Smirnov Z & & .937 & .603 \\
Asymp. Sig. (2-tailed) & & .343 & .861 \\
$\begin{array}{l}\text { a. Test distribution is Normal. } \\
\text { b. Calculated from data. }\end{array}$ & & \\
\hline
\end{tabular}

Table 6. Group Bs (Physical Class)

\begin{tabular}{llrr}
\hline \multicolumn{4}{c}{ One-Sample Kolmogorov-Smirnov Test } \\
N & & x & \multicolumn{1}{c}{ y } \\
\hline Normal & Mean & 8.89 & 19.63 \\
Parameters ${ }^{\mathrm{a}, \mathrm{b}}$ & Std. & 5.811 & 8.480 \\
& Deviation & & \\
Most Extreme & Absolute & .154 & .102 \\
Differences & Positive & .154 & .076 \\
& Negative & -.103 & -.102 \\
Kolmogorov-Smirnov Z & & .672 & .443 \\
Asymp. Sig. (2-tailed) & & .757 & .989 \\
$\begin{array}{l}\text { a. Test distribution is Normal. } \\
\text { b. Calculated from data. }\end{array}$ & & \\
\hline
\end{tabular}

Then, the data are calculated by using Wilcoxon Signed Ranked Test because the data in this research is non-parametric data (Prasetyo. B. 2014). The scores in two groups are calculated separately because they belong to different major. 


\section{Result and Discussion}

\subsection{The Effect of Short Course}

3.1.1 Group A (Social Class)

Table 7: Output of Wilcoxon Signed Ranks Test (Rank)

\begin{tabular}{llrrr}
\hline & \multicolumn{1}{c}{ N } & Mean Rank & Sum of Ranks \\
\hline Before - & Negative Ranks & $1^{\mathrm{a}}$ & 1.00 & 1.00 \\
After & Positive Ranks & $13^{\mathrm{b}}$ & 8.00 & 104.00 \\
& Ties & $0^{\mathrm{c}}$ & & \\
& Total & 14 & &
\end{tabular}

a. $y<x$

b. $y>x$

c. $y=x$

Table 8: Test Statistics

\begin{tabular}{lr}
\hline & After - Before \\
\hline Z & $-3.235^{\mathrm{b}}$ \\
Asymp. Sig. (2-tailed) & .001 \\
a. Wilcoxon Signed Ranks Test & \\
b. Based on negative ranks. & \\
\hline
\end{tabular}

3.1.2 Group B (Physical Class)

Table 9: Ranks

\begin{tabular}{llccc}
\hline & & $\mathrm{N}$ & Mean Rank Sum of Ranks \\
\hline Before - & Negative Ranks & $0^{\mathrm{a}}$ & .00 & .00 \\
After & Positive Ranks & $17^{\mathrm{b}}$ & 9.00 & 153.00 \\
& Ties & $2^{\mathrm{c}}$ & & \\
& Total & 19 & &
\end{tabular}

a. After $<$ Before

b. After $>$ Before

c. After $=$ Before

Table 10: Test Statistics ${ }^{\mathrm{a}}$

\begin{tabular}{lr}
\hline & After - Before \\
\hline$Z$ & $-3.623^{\mathrm{b}}$ \\
Asymp. Sig. (2-tailed) & .000 \\
a. Wilcoxon Signed Ranks Test & \\
b. Based on negative ranks. & \\
\hline
\end{tabular}

3.2 The Students' Score before and after the Short Course 3.2.1 Group A (Social Class)

Table 9: The Interval of the Students' Score

\begin{tabular}{|c|c|c|c|}
\hline \multirow[t]{2}{*}{ No. } & \multicolumn{2}{|c|}{ Score } & $\%$ \\
\hline & Pre-Test & Post-Test & Interval \\
\hline 1 & 20 & 19 & $0 \%$ \\
\hline 2 & 12 & 25 & $32.5 \%$ \\
\hline 3 & 8 & 13 & $12.5 \%$ \\
\hline 4 & 8 & 17 & $22.5 \%$ \\
\hline
\end{tabular}




\begin{tabular}{|c|c|c|c|}
\hline \multirow[t]{2}{*}{ No. } & \multicolumn{2}{|c|}{ Score } & \multirow{2}{*}{$\begin{array}{c}\% \\
\text { Interval }\end{array}$} \\
\hline & Pre-Test & Post-Test & \\
\hline 5 & 7 & 15 & $20 \%$ \\
\hline 6 & 6 & 15 & $22.5 \%$ \\
\hline 7 & 3 & 15 & $30 \%$ \\
\hline 8 & 3 & 19 & $40 \%$ \\
\hline 9 & 3 & 14 & $27.5 \%$ \\
\hline 10 & 3 & 21 & $45 \%$ \\
\hline 11 & 2 & 17 & $37.5 \%$ \\
\hline 12 & 1 & 16 & $37.5 \%$ \\
\hline 13 & 1 & 18 & $42.5 \%$ \\
\hline 14 & 0 & 16 & $40 \%$ \\
\hline
\end{tabular}

\subsubsection{Group B (Physical Class)}

Table 10: The Interval of the Students' Score

\begin{tabular}{lccc}
\hline No. & \multicolumn{2}{c}{ Score } & $\begin{array}{c}\% \\
\text { Interval }\end{array}$ \\
\hline 1 & 24 & 37 & $32.5 \%$ \\
2 & 16 & 18 & $7.5 \%$ \\
3 & 16 & 30 & $10 \%$ \\
4 & 13 & 25 & $55 \%$ \\
5 & 12 & 15 & $7.5 \%$ \\
6 & 12 & 12 & $0 \%$ \\
7 & 11 & 30 & $47.5 \%$ \\
8 & 10 & 22 & $30 \%$ \\
9 & 9 & 13 & $10 \%$ \\
10 & 7 & 18 & $27.5 \%$ \\
11 & 7 & 11 & $10 \%$ \\
12 & 7 & 27 & $50 \%$ \\
13 & 7 & 13 & $15 \%$ \\
14 & 5 & 15 & $25 \%$ \\
15 & 4 & 20 & $40 \%$ \\
16 & 3 & 25 & $22 \%$ \\
17 & 3 & 20 & $42.5 \%$ \\
18 & 3 & 22 & $47.5 \%$ \\
\hline
\end{tabular}

From the result of the Wilcoxon Signed Ranks Test, it is analyzed that the alpha value of both groups are less than 0.05. The Test Statistics shows that the alpha value at Asymp.Sig. (2-tailed) of group A (social class) is .001, and the alpha value of group B (physical class) is .000 . This result means that the hypothesis is rejected. In other words, that there is significant difference of the students' score before and after the short course. Based on the score before and after the short course of both groups, it is analyzed that the score of the students in group A (social class) increased up to $31.5 \%$, and the score of the students in group B (physical class) also increased up to $28.2 \%$. 


\section{Conclusion}

The analysis of the statistical calculation infers that there is significant effect of the short course to the students' ability in translating English verbal sentences. Furthermore, the short course is able to reduce the students' error in translating English verbal sentence. In other words, the short course affects significantly the students' ability in translating English verbal sentence that is proved by the increase of their score after the short course. It implies that they reduce making error in translating English verbal sentence. The conclusion of this research shows us that the short course works well to improve the students' ability in translating English verbal sentences. Therefore, it is recommended that this short course might be conducted with other students. In other words, a short course is potential enough to improve the students' knowledge, especially of English language. As seen in the schedule of the short course, it only needs three days. In these days, the researchers start the class with giving motivation, pre-test, treatment, and post-test. The content or the material in the short course might be different. It depends on the need in the field. Hopefully, this research contributes much for other research, especially those that are related to English language teaching.

\section{References}

[1] Clara P et.al. 2017. Translation Modalities: An Investigation of The Translated Short Story "Dez De Dezembro". Cadernos de Tradução. 37(2):80-100. Retrieved from DOI 10.5007/2175$7968.2017 \mathrm{v} 37 \mathrm{n} 2 \mathrm{p} 80$

[2] Kalmazova. N. 2016. Teaching Law Students Pre-Translation Text Analysis. Studies in Logic, Grammar and Rhetoric. 45(1):87-96. Retrieved from DOI 10.1515/slgr-2016-0017

[3] Nava, Andrea. 2017. Error and Learnig/Teaching English as a Second/Foreign Language: An Exercise in Grammaticology. Altre Modernità. 0(0):79-97. Retrieved from DOI 10.13130/2035$7680 / 8304$

[4] Horiguchi, Sachico. et.al. 2015. Voices from the Field. In Foreign Language Education in Japan: Exploring Qualitative Approach.: Sense Publishers. Pp 1-18. Rretrieved from DOI: https://doi.org/10.5565/rev/jt13.732

[5] Irawati, I \& Maharani, L. 2012. Teaching And Learning Writing Using Teacher's Written Feedback And Conference. Register Journal 5(1), 121-145. Retrieved from http://dx.doi.org/10.18326/rgt.v5i1.\%25p

[6] Pedro A. Fuertes-Olivera \& Carmen Piqué-Noguera. 2015. The Literal Translation Hypothesis in ESP Teaching/Learning Environments. Scripta Manent. 8(1).15-30. Retrieved from http://scriptamanent.sdutsj.edus.si/ScriptaManent/article/view/109/95

[7] Prasetyo. B. 2014. Metode Penelitian Kuantitative: Teori dan Aplikasi. Jakarta: PT. RajaGrafindo Persada.

[8] Richardson, V. 1997. Constructivist Teaching and Teacher Education: Theory and Practice. In Constructivist Teacher Education. London: The Falmer Press

[9] Seatter, C.S. \& Ceulemans, K. 2017. Sustainability in Higher Education Pedagogical Styles that Make a Difference. Canadian Journal of Higher Education 47(2). Retrieved from http://journals.sfu.ca/cjhe/index.php/cjhe/article/view/186284/pdf

[10] Tulegen, et.al. 2016. Grammatical Means of Temporality Expression in Translation. International Journal of Applied Linguistics and English Literature 6 (1). 202-208. Retrieved from http://dx.doi.org/10.7575/aiac.ijalel.v.6n.1p.202

[11] Wong. R.M.H. 2012. Linking Motivation and Pedagogi: The Case of Newly-Arrived Hong Kong Students. The Asia-Pacific Education Resercher 21(3). 636-647. Retrieved from https://ejournals.ph/article.php?id=4541 